\title{
Wspomnienie o Profesorze Karolu Joncy
}

Zmarły w roku 2008 profesor Karol Jonca był jednym z najwybitniejszych po II wojnie światowej polskich badaczy historii państwa i prawa oraz doktryn politycznych i prawnych. Wraz z nieżyjącymi już profesorami Konstantym Grzybowskim, Markiem Sobolewskim, Franciszkiem Ryszką, Juliuszem Bardachem, Janem Baszkiewiczem i innymi bez wątpienia należał do luminarzy nauk historycznoprawnych, ciesząc się uznaniem nie tylko w kraju, ale także za granicą. W całym swym ponadpięćdziesięcioletnim okresie działalności naukowej i dydaktycznej profesor Jonca zawsze odznaczał się ogromną pracowitością, skrupulatnością i sumiennością oraz rozległością zainteresowań badawczych i nieustanną gotowością dzielenia się swymi doświadczeniami zawodowymi. Jego niespożyta energia badawcza i zapał twórczy zyskiwały Mu tak wśród innych wysoko utytułowanych uczonych, jak i wśród młodszych kolegów po fachu oraz studentów niezmiennie wielki autorytet i szacunek. Profesor Jonca całą swoją karierę akademicką - od asystentury po studiach prawniczych po emeryturę - związał przede wszystkim z Wydziałem Prawa (z czasem z Wydziałem Prawa i Administracji, a ostatecznie z Wydziałem Prawa, Administracji i Ekonomii) Uniwersytetu Wrocławskiego, pozostając wierny tej uczelni niemal do ostatnich chwil życia, zawsze chętnie służąc jej swoimi cennymi radami. Można z przekonaniem stwierdzić, że profesor Jonca był całym sercem i bezgranicznie oddany sprawom swej uczelni. Jeszcze $\mathrm{w}$ okresie PRL zaangażował się $\mathrm{w}$ akcję zmierzającą do pozbawienia Uniwersytetu Wrocławskiego imienia jego komunistycznego patrona - Bolesława Bieruta, a następnie w inicjatywę budowy nowego gmachu Biblioteki Uniwersyteckiej.

Choć w stolicy Dolnego Śląska Karol Jonca osiadł już na samym początku drugiej połowy lat pięćdziesiątych ubiegłego stulecia, do końca życia odczuwał jednak - czemu dawał wielokrotnie dowód - szczególną więź z „krajem lat dziecinnych”, czyli Opolszczyzną, a zwłaszcza z Kędzierzynem-Koźlem 
i jego okolicami, gdzie się urodził ${ }^{1}$. Już jako nauczyciel akademicki niejednokrotnie zajmował się dziejami swej małej ojczyzny, publikując na ten temat większe i mniejsze rozprawy naukowe. Nie tylko tymi opracowaniami, ale także udziałem w licznych konferencjach naukowych i inicjatywach na rzecz Opolszczyzny profesor Jonca zasłużył sobie na wdzięczność jej mieszkańców. Nic też dziwnego, że niedawno jedna z ulic w Kędzierzynie-Koźlu otrzymała Jego imię, a jeszcze za życia nadano Mu godność honorowego obywatela tego miasta.

Związana z wrocławskim fakultetem prawniczym kariera naukowo-dydaktyczna profesora Karola Joncy może uchodzić za wzór godny naśladowania przez innych nauczycieli akademickich. Zaledwie cztery lata po ukończeniu studiów obronił On w Instytucie Historii PAN w Warszawie rozprawę doktorską (1958), uzyskując stopień doktora nauk humanistycznych. Sześć lat później uzyskał stopień doktora habilitowanego nauk prawnych i w tym samym 1964 r. otrzymał tytuł docenta. Również po sześciu latach - a więc szybko, mając czterdzieści jeden lat - uzyskał tytuł profesora nadzwyczajnego, a dziesięć lat później ukoronował swoje awanse akademickie tytułem profesora zwyczajnego. Warto podkreślić, że wszystkie wymienione stopnie i tytuły naukowe profesor Jonca zawdzięczał wyłącznie swojej pracowitości i rzetelności naukowej, a nie - jak to nierzadko bywało w czasach Polski Ludowej - przynależności do partii komunistycznej (PZPR). Karol Jonca nigdy zresztą nie wstąpił do tej partii, starając się zachować - na tyle na ile było to wówczas możliwe - niezależność światopoglądową, a w pewnych sytuacjach (tzw. wydarzenia marcowe z 1968 r. oraz okres stanu wojennego) bronił pracowników i studentów swego macierzystego fakultetu przed represjami ze strony władz komunistycznych. Brak przynależności do PZPR lub jej ,stronnictw sojuszniczych" (ZSL i SD) nie stanowił - na szczęście - do pewnego momentu przeszkody w sprawowaniu przez Niego niektórych funkcji na Wydziale Prawa Uniwersytetu Wrocławskiego. W latach 1966-1972 był On jego prodziekanem, a w latach 1972-1974 dziekanem. Z tego drugiego urzędu został jednak odwołany przez ówczesnego rektora Mariana Orzechowskiego. Jako powód pozbawienia profesora Joncy funkcji dziekana (w gruncie rzeczy jedynie pretekst) zostało podane rzekomo niewłaściwe przygotowanie Wydziału Prawa do akcji czynów społecznych, do podejmowania których władze PRL regularnie zmuszały jej obywateli. W rzeczywistości przyczyną zdjęcia Karola Joncy z tego urzędu była Jego - jak to się w Polsce Ludowej określało - ,politycznie niepewna postawa obywatelska”. Przy tej okazji Marian Orzechowski i inni działacze partyjni czynili Mu i niektórym jego współpracow-

${ }^{1}$ J. Wyrozumski, Karol Jonca (13 IX 1930-13 I 2008), Polska Akademia Umiejetności, Wykłady 1, Kraków 2011, s. 10 i n.; M. Sadowski, Z badań nad spuścizna naukowa Karola Joncy, (w:) Prawnicy na Uniwersytecie Wrocławskim, pod red. M. Marszała i J. Przygodzkiego, Wrocław 2012, s. 105 i n. 
nikom (m.in. Alfredowi Koniecznemu i Franciszkowi Połomskiemu) zupełnie absurdalny zarzut mający antyniemiecki wydźwięk. Wypominano im bowiem miejsce urodzenia na Śląsku Opolskim przed II wojną światową, czyli na obszarze Trzeciej Rzeszy, upatrując w tym fakcie okoliczność mogącą negatywnie wpływać na ,patriotyczną postawę” tych osób. Nieprzychylnie do profesora Joncy odnosił się nie tylko ówczesny rektor Uniwersytetu Wrocławskiego, ale także następca Joncy na urzędzie dziekana - docent Aleksander Patrzałek, będący podobnie jak Marian Orzechowski aktywnym członkiem PZPR.

Profesor Jonca nigdy nie dał się jednak zastraszyć przez komunistyczne władze i mimo niesprzyjających w latach siedemdziesiątych i osiemdziesiątych XX w. warunków politycznych nadal niestrudzenie prowadził badania naukowe i zajęcia dydaktyczne, odważnie głosząc dalekie od oficjalnej propagandy PRL poglądy na rolę i zadania środowiska akademickiego i domagając się poszanowania jego autonomii. Przez trzydzieści dwa lata pełnił (do 2000 r.) funkcję kierownika najpierw Zakładu, a następnie Katedry Doktryn Politycznych i Prawnych, skupiając wokół siebie grono uczniów, którym zawsze z życzliwością poświęcał swoją uwagę i czas. Po śmierci profesora Joncy w 2008 r. starają się oni kontynuować Jego dzieło. Jeden z nich uzyskał już kilkanaście lat temu tytuł profesora, kilku innych stopień doktora habilitowanego, a dziesięciu z nich stopień doktora. Warto dodać, że wśród tych ostatnich znalazł się naukowiec z Japonii - Shinsuke Hosoda, obecnie profesor Uniwersytetu w Kyoto, który doktoryzował się z dziedziny bardzo odległej od problematyki Dalekiego Wschodu, a mianowicie z fragmentu historii społecznej i gospodarczej Śląska w XIX w. ${ }^{2}$ Profesor Jonca był także promotorem trzech doktoratów honoris causa: Edmunda J. Osmańczyka (1988), Jerzego Giedryocia (1998) i Jana Baszkiewicza (2003). Ponadto wielokrotnie recenzował rozprawy doktorskie i habilitacyjne oraz wnioski o nadanie tytułów profesorskich.

Dokonana na przełomie lat osiemdziesiątych i dziewięćdziesiątych zmiana ustroju politycznego w Polsce przyczyniła się do jeszcze większej niż przedtem naukowej i organizacyjnej aktywności profesora Joncy. Formalna likwidacja systemu komunistycznego w naszym kraju stworzyła nie tylko dla Niego, ale także dla wielu innych uczonych pragnących pracować dla dobra Polski zachętę do urzeczywistnienia rozmaitych planów badań naukowych i kontaktów zagranicznych. Mimo nie najlepszego stanu zdrowia profesor Jonca nie szczędził sił i czasu, by polskie środowisko akademickie na trwałe zajęło ważne miejsce w jednoczącej się Europie i w ogóle na świecie. Już w 1989 r. jako wytrawny znawca problematyki niemieckiej podjął wraz gronem osób wywodzących się między innymi z wrocławskiego Klubu

2 S. Hosoda, Położenie socjalne robotników $w$ górnictwie węglowym $w$ dobrach książą pszczyńskich na Górnym Śląsu 1847-1870, Wrocław 1997. 
Inteligencji Katolickiej działania zmierzające do stworzenia przesłanek dla prawdziwego porozumienia polsko-niemieckiego. Wykorzystując swoje naukowe kontakty ze środowiskiem naukowym w RFN, w tym z tamtejszymi badaczami antyhitlerowskiej opozycji w Niemczech, przyczynił się do założenia we Wrocławiu w pierwszym roku transformacji ustrojowej w Polsce Fundacji Krzyżowa dla Porozumienia Europejskiego. Nazwa tej instytucji nie była przypadkowa. W podświdnickiej miejscowości Krzyżowa (Kreisau) na Dolnym Śląsku działała bowiem w okresie II wojny światowej opozycyjna wobec nazistowskiego reżimu grupa spiskowców skupiona wokół właściciela tamtejszego majątku ziemskiego hrabiego Helmutha Jamesa von Moltke. Już w tym miejscu dodam, że profesor Jonca jeszcze w okresie PRL podjął naukowe badania nad tym nurtem opozycji antyhitlerowskiej. Przez wiele lat utrzymywał kontakty z wdową po Moltkem - Freyą, która zawsze życzliwie wspierała Fundację Krzyżowa, wielokrotnie odwiedzając swój dawny majątek. Na samym początku przemian ustrojowych w Polsce profesor Jonca przyczynił się również do utworzenia we Wrocławiu towarzystwa imienia wybitnej intelektualistki niemieckiej pochodzenia żydowskiego, zamordowanej przez nazistów zakonnicy Edyty Stein, kanonizowanej przez papieża Jana Pawła II. Swoją rozległą wiedzą z zakresu niemcoznawstwa oraz autorytetem obiektywnego uczonego wyczulonego na sprawy polsko-niemieckie wspierał także Centrum Studiów Niemieckich i Europejskich im. Willy'ego Brandta w Uniwersytecie Wrocławskim, zasiadając przez kilka lat w jego Radzie Naukowej (2002-2007).

$\mathrm{Na}$ tym bynajmniej nie koniec wzmożonej aktywności naukowej i organizacyjnej profesora Joncy w okresie Trzeciej Rzeczypospolitej. Już na samym początku lat dziewięćdziesiątych zaangażował się On w tworzenie podwalin pod odrodzenie starej uczelni Viadrina, która pod nazwą „Uniwersytet Europejski" ponownie założona została wtedy we Frankfurcie nad Odrą, przyjmując na studia również młodzież spoza Niemiec, w tym z Polski. Od 1993 r. przez wiele następnych lat Karol Jonca prowadził na tej uczelni (w ramach Collegium Polonicum) zajęcia dydaktyczne z historii państwa i prawa polskiego. W uznaniu zasług dla Uniwersytetu Viadrina jego Senat nadał w 2001 r. profesorowi Joncy zaszczytny tytuł doktora honoris causa. Jeszcze przed 1989 r. aktywnie uczestniczył On w pracach polsko-niemieckiej komisji podręcznikowej UNESCO, wykazując się postawą polskiego patrioty. Jako wieloletni współpracownik profesora Joncy mogę z pełnym przekonaniem stwierdzić, że Jego dbałość o polską rację stanu i interesy narodowe nigdy nie miała jednak nic wspólnego z poglądami nacjonalistycznymi, lecz zawsze wynikała z dążenia do naukowego obiektywizmu. Wielokrotnie dawał temu dowód także poza działalnością we wspomnianej komisji podręcznikowej. Profesor Jonca mógł się poszczycić przynależnością do licznych instytutów i towarzystw naukowych. Wymienię tu Jego aktywny udział w pracach Insty- 
tutu Śląskiego w Opolu i Instytutu Zachodniego w Poznaniu, Głównej Komisji Badania Zbrodni Hitlerowskich w Polsce i Instytutu Pamięci Narodowej czy francuskiej organizacji Nuit et Brouillard (Noc i Mgła) skupiającej byłych uczestników II wojny światowej represjonowanych przez nazistów.

Na uznanie zasługuje działalność edytorska Karola Joncy. W latach 1967-1976 był On zastępcą redaktora naczelnego, a w latach 1976-1986 redaktorem naczelnym „Studiów Śląskich” wydawanych w Opolu. Szczególnym osiągnięciem edytorskim profesora Joncy było założenie w 1974 r. w ramach Acta Universitatis Wratislaviensis „Studiów nad Faszyzmem i Zbrodniami Hitlerowskimi" - jedynego takiego periodyku naukowego w Polsce, unikatowego również na skalę światową. Należy podkreślić, że już w okresie PRL zyskał on wysoką renomę nie tylko w kraju, ale także zagranicą. Na jego łamach zamieszczali (i nadal zamieszczają) swoje artykuły najwybitniejsi polscy i zagraniczni znawcy tej problematyki, między innymi Franciszek Ryszka, Henryk Olszewski, Ursula Büttner, Werner Jochmann, Ernst Nolte, Roland Wittmann, Anthony Polonsky. Profesor Jonca pełnił z ogromnym zaangażowaniem funkcję redaktora naczelnego „Studiów” nieprzerwanie przez trzydzieści trzy lata (do 2007 r.). W tym czasie drukiem ukazało się dwadzieścia dziewięć opasłych tomów tego periodyku. Z czasem zaczęły pojawiać się w nim również teksty dotyczące nie tylko faszyzmu i nazizmu oraz zbrodni hitlerowskich, lecz także w ogóle autorytaryzmu i totalitaryzmu, w tym sowieckiego systemu ustrojowego.

W prezentacji przejawów naukowej aktywności profesora Joncy nie może zabraknąć jeszcze innych informacji o Jego dokonaniach. W uznaniu swych wybitnych zasług $\mathrm{w}$ tej dziedzinie przez środowisko uczonych został On w 1995 r. powołany na członka korespondenta Polskiej Akademii Umiejętności w Krakowie. Przynależność do tej prestiżowej instytucji poczytywał sobie za szczególny zaszczyt, niemal do końca swego życia aktywnie uczestnicząc w jej pracach. Przez wiele lat Profesor chętnie udzielał się również w licznych krajowych i zagranicznych konferencjach naukowych. Jako referent, stypendysta lub visiting professor najczęściej przebywał w RFN (Bonn, Monachium, Hamburg, Berlin, Koblencja). Referaty lub wykłady wygłaszał także w USA, Kanadzie, Norwegii, Austrii, Francji, Holandii, Izraelu, ZSRR i na Węgrzech. Ożywione kontakty naukowe utrzymywał z wieloma zagranicznymi ośrodkami akademickimi, między innymi z Institut für Zeitgeschichte w Monachium (prof. M. Broszat), Forschungsstelle für die Geschichte des Nationalsozialismus w Hamburgu (prof. W. Jochmann) i Politisches Seminar Uniwersytetu w Bonn (prof. H.-A. Jacobsen) oraz z Yad Vashem w Jerozolimie i Leo Baeck Institute w Londynie. Warto podkreślić, że profesor Jonca był jednym z głównych organizatorów międzynarodowej konferencji we Wrocławiu w 1974 r. na temat teorii i praktyki faszyzmu w Europie w latach 1922-1945. Skupiła ona wielu wybitnych znawców tej problematyki z różnych krajów, którzy po 
raz pierwszy mieli wtedy w Polsce okazję dyskutować o niej na tak szerokim forum, dzieląc się swoimi doświadczeniami naukowymi. Już w tamtym okresie kierowany przez profesora Joncę zespół naukowy wyrósł na jeden z czołowych w kraju ośrodków badania doktryny, ustroju i prawa nazistowskiego, zyskując uznanie także poza Polską. Nie sposób zaprzeczyć, że już na począt$\mathrm{ku}$ lat siedemdziesiątych XX w. profesor Jonca stał się - obok między innymi Franciszka Ryszki - jednym z największych autorytetów naukowych w tej dziedzinie. To za Jego sprawą i z Jego inspiracji niektórzy młodzi nauczyciele akademiccy (w tym piszący te słowa) skierowali wtedy swoje naukowe zainteresowania właśnie na zagadnienia teorii i praktyki faszyzmu.

Profesor Jonca pozostawił po sobie ogromną spuściznę naukową, która na trwale weszła do polskiego dziedzictwa intelektualnego. Jego dorobek obejmuje około czterysta publikacji w kilku językach: od monografii książkowych poczynając a na drobniejszych tekstach kończąc. Na tematykę badań naukowych prowadzonych przez Karola Joncę, zwłaszcza w początkowym okresie Jego kariery akademickiej, znaczny wpływ wywarł Jego nauczyciel i mistrz - pochodzący z Wilna profesor Seweryn Wysłouch, który tuż po II wojnie światowej tworzył na wrocławskim fakultecie prawniczym zręby nauk historycznoprawnych. Za cel postawił sobie skupienie wokół siebie grupy młodych, pełnych twórczego zapału naukowców (wśród nich m.in. byli K. Jonca, F. Ryszka, K. Orzechowski, A. Konieczny i F. Połomski), starając się zaszczepić w nich - zresztą skutecznie - pragnienie poznania dziejów ustroju i prawa na Śląsku od średniowiecza po czasy współczesne. Profesor Wysłouch uważał bowiem tę rozległą problematykę za szczególnie wymagającą opracowania przez polskich badaczy związanych ze Śląskiem ze względu na swoje pochodzenie i miejsce zamieszkania. W ten sposób zamierzał nadrobić wieloletnie zaniedbania w tej dziedzinie ze strony polskich historyków, którzy w zasadzie nie zajmowali się - w przeciwieństwie do niemieckich naukowców - przed 1945 r. dziejami Śląska. Tak więc za namową Seweryna Wysłoucha młody Karol Jonca rozpoczął swoją ,przygodę" z nauką od penetracji problematyki śląskiej. Jego zainteresowanie dziejami tego obszaru okazało się tak głębokie i silne, że do końca swego życia nie zaprzestał On odnośnych badań naukowych, nieustannie poszerzając zakres swych dociekań na temat ustroju, instytucji, myśli politycznej i prawa na Śląsku. Nie ulega wątpliwości, że wskazane zagadnienia stanowiły jeden $\mathrm{z}$ głównych nurtów badań prowadzonych przez profesora Joncę.

Jego pierwsze naukowe fascynacje historią Śląska dotyczyły sytuacji społecznej i gospodarczej na tym obszarze od około połowy XIX w. do I wojny światowej. Ukoronowaniem badań nad tą problematyką były dwie - oparte na rozległej kwerendzie archiwalnej - monografie książkowe: Położenie robotników w przemyśle górniczo-hutniczym na Śląsku w latach 1889-1914 (1960) oraz Polityka socjalna Niemiec w przemyśle ciężkim Górnego Ślaska 
1871-1914 (1966). Pierwsza z nich stanowiła zmodyfikowaną wersję rozprawy doktorskiej, druga zaś była rozprawą habilitacyjną. Karol Jonca przekonująco udowodnił w tych oraz $w$ innych swych publikacjach, że położenie robotników zatrudnionych w przemyśle ciężkim na Śląsku w omawianym przez Niego okresie systematycznie się poprawiało, między innymi wskutek odpowiedniej polityki socjalnej władz niemieckich. Jak trafnie zauważył Mirosław Sadowski, tezy i wnioski Autora „,nie zawsze odpowiadały marksistowskoleninowskiej wizji dziejów", która była niemal obowiązującym kanonem badawczym w okresie PRL ${ }^{3}$. Przynajmniej niektóre konkluzje zawarte w rzeczonej monografii nie były zatem po myśli oficjalnej doktryny naukowej.

Zainteresowania profesora Joncy problematyką śląską bynajmniej nie ograniczały się do wskazanych zagadnień. Już kilkadziesiąt lat temu podjął się On opracowania historii bliskich swemu sercu dwóch miast: Strzelec Opolskich oraz Kędzierzyna-Koźla. Niedługo przed śmiercią opublikował monografię swojej rodzinnej miejscowości - Sławięcic ${ }^{4}$. Należy podkreślić, że profesor Jonca raczej incydentalnie, choć jak zawsze z pasją badawczą zajmował się lokalną historią Śląska. Niewątpliwie większą wagę przykładał do analizy szerszych i bardziej złożonych oraz przekrojowych kwestii naukowych, choć nierzadko rozpatrywanych przez Niego także w odniesieniu do Śląska. Tego wyrazem jest wydana w 1970 r. obszerna monografia książkowa Polityka narodowościowa Trzeciej Rzeszy na Śląsku Opolskim 1933-1940. Studium polityczno-prawne. Rzeczona rozprawa tematycznie należy do kolejnego - po zagadnieniach z dziejów społecznych i gospodarczych Śląska - dużego wątku badawczego podejmowanego przez Karola Joncę, a mianowicie do rozległej problematyki nazizmu. Będzie jeszcze o tym mowa w dalszej części moich wywodów. W tym miejscu należy wskazać, że w monografii o polityce narodowościowej Niemiec hitlerowskich Autor wnikliwie ukazał stosunek władz Trzeciej Rzeszy do mniejszości polskiej i żydowskiej w okresie obowiązywania na Górnym Śląsku konwencji genewskiej z 1922 r. oraz w okresie kilku lat po jej wygaśnięciu (1937).

Problematyka śląska $\mathrm{w}$ badaniach profesora Joncy przewija się jeszcze w wielu innych Jego publikacjach. I tak, Śląsk stał się miejscem opisywanych przez Niego wydarzeń związanych z wojnami napoleońskimi. Zafascynowany nimi opublikował On - już po przejściu w 2000 r. na emeryturę - monografię książkową na ten temat, poprzedzając jej wydanie kilkoma drobniejszymi opracowaniami ${ }^{5}$. Wyraźne odniesienia do Śląska zawierają także publikacje Karola Joncy dotyczące takich zagadnień, jak prześladowania Żydów w Trzeciej Rzeszy oraz relacji między władzami tego państwa i Kościołami chrześcijańskimi w Niemczech. Kolejnym wątkiem prowadzonych przez

\footnotetext{
${ }^{3}$ M. Sadowski, op. cit., s. 108 .

${ }^{4}$ K. Jonca, Dzieje Stawięcic do roku 1945, Kędzierzyn-Koźle-Sławięcice 2007.

${ }^{5}$ K. Jonca, Wielka armia Napoleona w kampanii 1807 r. pod Koźlem, Opole 2004.
} 
Niego badań - związanych z historią Śląska - była emigracja do Ameryki Północnej (przede wszystkim do Teksasu) części mieszkańców Opolszczyzny (w tym licznej rodziny Moczygembów z Płużnicy Wielkiej) od około połowy XIX w. Profesor Jonca w licznych artykułach i studiach wnikliwie prześledził przyczyny, przebieg i skutki tej emigracji. Jak zwykle w swych publikacjach, wywody na ten temat oparł na rozległej bazie źródłowej. Dodam, że kilka drobniejszych opracowań poświęcił także wybitnym politykom pochodzącym ze Śląska: Arce Bożkowi, Wojciechowi Korfantemu i Edmundowi J. Osmańczykowi.

Z zainteresowania szeroko rozumianą problematyką śląską poniekąd wzięły się również Jego (wspólne ze wspomnianym A. Koniecznym) archiwalne badania nad dziejami Wrocławia w okresie II wojny światowej. W rezultacie tych badań powstały na początku lat sześćdziesiątych ubiegłego stulecia dwa obszerne opracowania o twierdzy Wrocław (Festung Breslau) ${ }^{6}$. Wspólnie z Alfredem Koniecznym profesor Jonca opublikował również (po raz pierwszy w 1964 r.) niezmiernie cenną źródłowo i stanowiącą pasjonującą lekturę kronikę oblężenia Wrocławia pod koniec II wojny światowej, prowadzoną przez niemieckiego proboszcza parafii św. Maurycego - ks. Paula Peikerta. O wielkiej wartości historycznej tego opracowania - przetłumaczonego przez obu badaczy na polski i poprzedzonego obszernym wstępem naukowym - świadczy spora liczba jego wznowień. Do 2005 r. ukazało się drukiem aż osiem wydań kroniki Peikerta. Osiem wznowień miała także jej oryginalna wersja w języku niemieckim, która wzbudziła spore zainteresowanie czytelników i w RFN, i w NRD.

Pewne związki z badaniami profesora Joncy nad dziejami Śląska można dostrzec co najmniej jeszcze w dwóch innych obszarach Jego naukowych zainteresowań. Jednym z nich była problematyka historii gospodarczej Polski okresu feudalizmu i kapitalizmu. Zawarte między innymi w trzech podręcznikach akademickich wywody na ten temat doprowadził On do okresu przed wybuchem II wojny światowej ${ }^{7}$. W każdym z tych opracowań sporo miejsca zajmują - choć bynajmniej nie dominują - rozważania dotyczące kształtowania się stosunków społecznych i ekonomicznych na Śląsku. Jak rzadko kto Karol Jonca posiadł gruntowną i rozległą wiedzę na ten temat, wzbogaconą o doskonałą znajomość kwestii ustrojowo-prawnych i politycznych na tym obszarze. W tym miejscu dodam, że zanim zaczął On parać się od końca lat sześćdziesiątych XX w. doktrynami politycznymi i prawnymi, przez kilkanaście lat zajmował się historią państwa i prawa polskiego, prowadząc zajęcia

${ }^{6}$ Pierwsze z nich nosiło tytuł „,Festung Breslau” - Documenta obsidionis (Wrocław 1962), drugie zostało przez obu autorów zatytułowane Upadek „,Festung Breslau” (Wrocław 1963).

${ }^{7}$ K. Jonca, Historia gospodarcza Polski w zarysie do 1939 roku (skrypt akademicki), Wrocław 1984; Dzieje gospodarcze Polski do 1939 roku, Wrocław 1996; Rozwój gospodarczy Polski do 1939 roku, Wrocław 2000 (wyd. I), Wrocław 2001 (wyd. II). 
dydaktyczne z tego przedmiotu. Wracając jeszcze do śląskoznawczych badań profesora Joncy: w latach dziewięćdziesiątych minionego stulecia opublikował On (wraz z zespołem współpracowników) obszerne opracowanie źródłowe na temat wysiedlenia Niemców i osadnictwa ludności polskiej na obszarze Krzyżowa-Świdnica po II wojnie światowej ${ }^{8}$. Wybór tych miejsc geograficznych jako przedmiotu odnośnych badań nie był przypadkowy. Przypomnę, że właśnie w Krzyżowej zawiązała się podczas II wojny światowej opozycyjna wobec dyktatury hitlerowskiej grupa spiskowców na czele ze wspomnianym hr. von Moltkem. Opracowanie prof. Joncy i kilku innych naukowców wrocławskich na temat tamtejszej rodzimej i napływowej ludności w latach 19451948 było pierwszą tak obszerną publikacją w Polsce po upadku komunizmu, podejmującą w obiektywny sposób (bez posługiwania się emocjonalnie i politycznie obciążonym określeniem „wypędzenie” - Vertreibung) problematykę wysiedleń Niemców i osadnictwa Polaków na byłych wschodnich obszarach Rzeszy.

Jak już wzmiankowałem, Karol Jonca był jednym z największych w Polsce autorytetów w dziedzinie badań nad nazizmem. W zakresie Jego zainteresowań tą rozległą problematyką mieściły się nie tylko takie kwestie naukowe, jak wskazane już zagadnienia dotyczące polityki narodowościowej Trzeciej Rzeszy, prześladowania Żydów i stosowanych wobec nich represji przez reżim hitlerowski, relacji między władzami narodowosocjalistycznymi i Kościołami chrześcijańskimi czy opozycji antynazistowskiej w Niemczech. Nie sposób wymienić wszystkich publikacji Profesora Joncy na wymienione tematy, ze względu na ogromną liczbę tych opracowań. Niewątpliwie jednym z Jego najważniejszych osiągnięć w tych dziedzinach jest obszerna, dwukrotnie wydana (1992 i 1998) monografia książkowa Noc kryształowa $i$ casus Herszela Grynszpana, w której znakomicie ukazał przyczyny, przebieg i skutki pogromu Żydów w Niemczech w listopadzie 1938 r., stanowiącego zapowiedź dalszych, jeszcze bardziej okrutnych represji wobec tej ludności z jej Holocaustem na czele. $Z$ innych publikacji Karola Joncy odnoszących się do wskazanych zagadnień należy wymienić cykl artykułów i studiów (regularnie zamieszczanych m.in. w ,Studiach nad Faszyzmem i Zbrodniami Hitlerowskimi" oraz innych renomowanych periodykach naukowych) o założeniach nazistowskiego rasizmu i antysemityzmu, poglądach i działalności kardynała Adolfa Bertrama w okresie Trzeciej Rzeszy czy o dziejach prawicowej opozycji antyhitlerowskiej (tzw. Kreisauer-Kreis i zamach na Hitlera w lipcu 1944 r.).

${ }^{8}$ Wysiedlenia Niemców i osadnictwo ludności polskiej na obszarze Krzyżowa-Świdnica (Kreisau-Schweidnitz) w latach 1945-1948/ Die Aussiedlung der Deutschen und die Ansiedlung der polnischen Bevölkerung im Raum Krzyżowa-Świdnica (Kreisau-Schweidnitz) 1945-1948. Dokumentenauswahl mit Einleitung, pod red. K. Joncy i M. Maciejewskiego (współpraca M. Marszał, K. Ruchniewicz, M. Sadowski, T. Scheffler), Wrocław 1997. 
Zakres naukowych zainteresowań profesora Joncy nazizmem obejmował w ogóle problematykę państwa i prawa w totalitaryzmie na przykładzie Trzeciej Rzeszy jako „państwa stanu wyjątkowego”: jego doktryn politycznych i prawnych, funkcjonowania jego organów władzy i wymiaru sprawiedliwości. Niejedno opracowanie Jego autorstwa dotyczy między innymi koncepcji znanego prawnika Carla Schmitta czy zaniku w Niemczech hitlerowskich idei państwa prawnego (Rechtsstaat). Osobno zajął się analizą poglądów nazistowskiego profesora prawa międzynarodowego Gustava Walza, który w latach trzydziestych pełnił funkcję rektora Uniwersytetu Wrocławskiego, narzucając $w$ bezwzględny sposób tej uczelni zasady funkcjonowania oparte na typowej dla Trzeciej Rzeszy idei wodzostwa. W ramach prowadzonych (wraz z A. Koniecznym) badań nad polityką okupacyjną Trzeciej Rzeszy podczas II wojny światowej profesor Jonca zajął się na przełomie lat siedemdziesiątych i osiemdziesiątych XX w. opracowaniem akcji pod kryptonimem „Noc i Mgła" (Nacht und Nebel) zwalczania przez władze nazistowskie przeciwników Niemiec na zachodzie Europy. Efektem badań w tej dziedzinie stała się obszerna monografia w języku francuskim z $1981 \mathrm{r}^{9}$

W swym rozległym dorobku naukowym Karol Jonca miał także publikacje nie łączące się wyraźnie z problematyką szeroko rozumianego nazizmu bądź zupełnie z nią niezwiązane. Od młodości fascynowały Go - o czym często i chętnie opowiadał - dzieje wojen i w ogóle sprawy wojskowe. Znał się na nich nie tylko jako uczony, ale również jako kolekcjoner militariów. Nic zatem dziwnego, że napisał niezmiernie ciekawe teksty nie tylko o wspomnianych już wojnach napoleońskich, lecz ponadto o niemieckiej doktrynie wojennej w XIX w., w tym o poglądach Helmuta von Moltkego Starszego i jego stosunku do Polski. Był autorem prac o doktrynie wojennej Adolfa Hitlera i o sporach wokół wybuchu wojny Trzeciej Rzeszy ze Związkiem Sowieckim (Fall Barbarossa). U schyłku życia podjął się opracowania unikatowych, przez nikogo przed Nim naukowo niespożytkowanych niemieckich dokumentów dyplomatycznych dotyczących wojny polsko-bolszewickiej w 1920 r. ${ }^{10}$ Zainteresowania profesora Joncy problematyką wojenną zaowocowały jeszcze innymi ciekawymi publikacjami. Wśród nich należy koniecznie wymienić Jego monografię książkową na temat czechosłowackiej doktryny polityczno-prawnej w odniesieniu do Niemców w latach 1920-1945, której wyrazem stały się dekrety prezydenta Edwarda Beneša ${ }^{11}$. Na tej podstawie prawnej Niemcy mieszkający po zakończeniu II wojny światowej w Czecho-

${ }^{9}$ K. Jonca, A. Konieczny, Nuit et Brouillard. L'operations terroriste nazie 1941-1944, Claviers 1981.

${ }^{10} \mathrm{~K}$. Jonca, Wojna polsko-sowiecka 1920 r. w dokumentach niemieckiej dyplomacji, Wrocław 2002.

${ }^{11}$ Idem, Dekrety prezydenta Edvarda Beneša. Niemcy w czechostowackiej doktrynie politycznej i prawnej z lat 1920-1945, Wrocław 2005. 
słowacji (przede wszystkim na obszarze przymusowo przyłączonych przed 1939 r. do Rzeszy Sudetów) zostali pozbawieni swej własności i wysiedleni z tego państwa. Jak we wszystkich pozostałych swych publikacjach, tak i w tym opracowaniu profesor Jonca zabłysnął jako znakomity badacz źródeł potrafiący umiejętnie wykorzystać płynącą z nich wiedzę do celów naukowej analizy. 